\title{
Editorial
}

\section{A new model for assessing the risk of banking crises}

Claudio Borio of the Bank for International Settlements and Philip Lowe of the Reserve Bank of Australia have put forward a new model aimed at better predicting the onset of banking crises. In their paper, published by the Bank for International Settlements, ${ }^{1}$ Borio and Lowe build on an earlier work arguing that it may be feasible to predict with reasonable levels of confidence the likelihood of banking crises developing by analysing the developments of certain vulnerabilities associated with the onset of banking crises. Under their model, analysis of the interaction of a small number of variables is used to give insight into the cumulative process that gives rise to banking distress.

As part of their analysis, Borio and Lowe consider the origins of past banking crises drawing four principal observations. First, that crises have a tendency to appear in circumstances of deteriorating economic fundamentals and, particularly, declines in asset quality rather than arbitrary investor decisions. Secondly, banking crises that can be viewed as significant in terms of their wider economic impact on GDP are often the result of the exposure of a number of institutions to common risk factors. The examples given by Borio and Lowe include broad asset classes such as property and equities and that because of this banking crises not only reflect but contribute to the volatility of GDP. Thirdly, problems develop and escalate over time in a definite cycle, in reflection of the interaction between the real economy and the financial sector; with expansion comes increased confidence and increased pricing of assets, with a concomitant perception that risk has declined, which all combines to create a potential for economic conditions to mask financial imbalances. Fourthly, the duo observe that while accurately predicting the timing of a crisis may not be a possibility, there should be a real possibility of being able to identify the symptoms that are likely to lead to the onset of a financial crisis.

Having made these observations, the pair argue that many of the banking crises that have occurred in the last 25 years display the characteristics they have identified. In particular, they point to the Nordic countries and Japan, the economic crises in the USA, the UK and Australia at the beginning of the 1990s, the crises in emerging Latin American economies in the latter part of the 1970s and the early years of the 1980s, as well as the Asian crisis towards the close of the 1990s.

The question the paper sets out to answer is whether vulnerabilities can be identified at a sufficiently early stage to allow for policy decisions to be taken that could avert financial crises taking place. The authors propose a model to enable such corrective action to be taken based on the adoption of a number of indicators they have assessed as effective in predicting banking crises.

At the heart of the authors' model lies the proposition that only a small combined number of variables need be considered in order to identify developing vulnerabilities and that the emphasis on just a small 
number of variables will be likely to improve the reliability of corresponding indicators. The model proposes three core variables: the ratio of private sector credit to GDP, equity prices and the real effective exchange rate.

In addition to the core variables, the model proposes using deviations from trends of the core variables in the belief that any significant move of the core variables away from the trend is indicative of imbalances that may be precursors to a banking crisis. The model only considers a deviation by a particular variable to be a warning of potential impending crisis if the corresponding variable is also in deviation. Thus, the authors consider four combinations of indicators: credit and asset prices, credit and exchange rate, credit and either the asset prices or exchange rate, credit and asset prices and the exchange rate.

Borio and Lowe's analysis suggests the model would have enabled early prediction of the majority of the banking crises they studied between 1960 and 1999, drawing the conclusion that the creation of an effective banking crisis early warning system based on simple composite indicators is feasible.

While recognising certain caveats concerning the variable nature of banking crises, the problems associated with the reliability of using past experience to predict future expectations and the changing nature of the international financial architecture, the authors conclude that their findings form a useful foundation for continued research.

\section{References}

(1) Borio, C. and Lowe, P. (2002) 'Assessing the risk of banking crises', BIS Quarterly Review, December. Available on the web at: www.bis.org/publ/r_qt0212.htm.

Paul Clement IALS Editor January 2003 